\title{
Molecular Mechanisms of Arterial Stiffening
}

\author{
Marina Cecelja Phil Chowienczyk
}

King's College London British Heart Foundation Centre, Department of Clinical

Pharmacology, St. Thomas' Hospital, London, UK

\section{Key Words}

Arterial calcification · Arterial stiffening · Cardiovascular disease · Genomic studies .

Vascular aging

\begin{abstract}
Stiffening of large arteries is a hallmark of vascular aging and one of the most important determinants of the age-related increase in blood pressure and cardiovascular disease events. Despite a substantial genetic component, the molecular mechanisms underlying phenotypic variability in arterial stiffness remain unknown. Previous genetic studies have identified several genetic variants that are associated with measures of arterial stiffness. Here, we review the relevant advances in the identification of pathways underlying arterial stiffness from genomic studies.

\section{Arterial Stiffness as a Risk Factor and Target for Treatment}

Stiffening of the aorta and large elastic arteries is a hallmark of vascular aging [1]. It has a number of adverse haemodynamic consequences, including a major contribution to isolated systolic hypertension [2-4]. When measured by aortic pulse wave velocity (aPWV), it is highly predictive of clinical cardiovascular disease events independent of blood pressure, both in the general population and in groups with additional risk factors [5, 6]. Formerly thought to be simply a marker of atherosclerosis [7], the pathology of aortic stiffening may differ, at least in part, from that of atherosclerosis [8-10]. Thus, in primate models of atherosclerosis, aPWV is reduced compared to non-atherosclerotic controls, at least in the early stages of atheroscle- 
Cecelja and Chowienczyk: Molecular Mechanisms of Arterial Stiffening

rosis [10]. In humans, aPWV is largely independent of risk factors other than age and blood pressure [11] and is not elevated in the presence of non-calcified atheromatous plaque [8,9]. The prognostic importance of arterial stiffening and the fact that it may be driven by a specific pathology distinct from atherosclerosis makes it an appealing target to prevent cardiovascular disease events.

\section{Arterial Calcification as a Cause of Arterial Stiffening}

In older subjects, calcification occurs in the media of the arterial wall around elastin fibres ('elastocalcinosis') [12] and within atherosclerotic plaque in the intima [13]. Although often regarded as distinct entities, intimal and medial calcifications often coexist. Arterial stiffening is closely associated with calcification, an association that could be explained by coexistent atherosclerosis [7]. However, animal models show that medial calcification (in the absence of atherosclerosis) increases arterial stiffness, suggesting a direct causal relation between calcification and stiffening [14]. Using combined computed tomography and magnetic resonance imaging to measure calcification and atheroma in the Twins UK population, we have shown that even though calcification often colocalises with atherosclerotic plaque, the association of stiffness with calcification is not explained by coexistent atheromatous plaque [8]. Furthermore, the correlation between calcification and stiffness is explained by shared genetic factors distinct from those responsible for atherosclerosis $[8,9]$.

Arterial calcification is now known to be an active process resembling osteogenesis in which vascular smooth muscle cells undergo osteoblastic differentiation, expressing many of the proteins associated with bone formation [13] and releasing vesicles into the extracellular matrix which serve as nucleation sites for the accumulation of hydroxyapatite crystals [15, 16]. In culture media, high concentrations of calcium and phosphate induce osteoblastic differentiation of vascular smooth muscle cells $[16,17]$. Pre-dialysis- and dialysis-dependent patients with chronic kidney diseases have high circulating calcium phosphate products and develop extensive calcification and arterial stiffening [18]. Precipitation of calcium in tissue in healthy subjects is inhibited by numerous regulatory factors including matrix gla protein, fetuin, klotho and fibroblast growth factor 23 [13]. It is likely that initiation and progression of calcification is dependent on the complex interactions between promoters and inhibitors of calcification.

\section{Contribution of Changes in the Extracellular Matrix}

Whilst calcification may represent the later stages of a degenerative arteriosclerotic process that can be detected macroscopically, it is likely to be initiated by elastin degradation and a change in the type of collagen, which may also contribute to arterial stiffening independent of calcification [14]. Such a degenerative process may relate to repetitive mechanical stress (heart rate $\times$ blood pressure product) [19]. It is thought to promote calcification through elastin-derived soluble peptides (matrikines or elastokines) which activate smooth muscle cell osteogenic differentiation [20] and increase matrix affinity for nucleating mineral deposition [21]. Matrix metalloproteinases (MMPs) degrade components of the extracellular matrix including elastin, and in vivo, MMP-mediated elastin degradation is closely associated with both medial calcification and increased arterial stiffness [22, 23]. MMPs are also implicated in cutaneous elastin degradation that may parallel changes in the arterial wall $[24,25]$. 
Cecelja and Chowienczyk: Molecular Mechanisms of Arterial Stiffening

\section{Genetics of Arterial Stiffness}

Heritability of arterial stiffness is approximately $40 \%$ as estimated from twin and family studies [26-28]. Candidate gene approaches have identified single-nucleotide polymorphisms related to arterial stiffness on genes potentially implicated in the regulation of the extracellular matrix and calcification: MMPs [29, 30], collagen 1 [31], fibrillin 1 [32] and ectonucleotide pyrophosphatase/phosphodiesterase 1 (ENPP1, an inhibitor of calcification) [33] in addition to genes relating to blood pressure regulation [34-36], and inflammation [37, 38]. Genome-wide association studies (GWAS) have only identified a small number of genetic variants reaching genome-wide significance. The collagen type IV alpha 1 (COL4A1) gene polymorphism on chromosome 13 (collagen type 4) was significantly associated with higher arterial stiffness [39] in one study, but the association failed to be replicated in a recent GWAS meta-analysis of 11 community-based cohorts. A significant association in the $3^{\prime}$-B-cell lymphoma/leukaemia 11B (3'-BCL11B) gene desert located on chromosome 14 did achieve genome-wide significance, but its potential role in arterial stiffening remains to be established [40].

The limitations of GWAS in identifying causal genes in hypertension, arterial stiffness and other common conditions are increasingly recognised and include limited power to identify common variants with a modest effect size, lack of coverage of rare variants, genetic interactions and gene $\times$ environment interactions [41, 42]. In addition, identified single-nucleotide polymorphisms are often located in intergenic or non-coding regions, and it is not clear which gene is the causal gene or the regulatory pathway/network. Thus, it is of interest to examine whether gene expression, an intermediate step between genetic variation and structural and functional variation, may be related more closely to the phenotype.

Blood-based gene expression tests have previously been associated with a wide range of non-haematological disorders including coronary artery disease [43-46] and hypertension [47]. While the exact nature of these associations remains unknown, they may either reflect parallel changes in gene expression across tissues or participation of haematological factors in the disease process. Where similar pathways may operate in parallel in vascular and nonvascular tissues, there may be a direct correlation of gene expression in sample tissues with arterial tissue. MMP9 expression in the skin, for example, has been shown to relate to arterial stiffness [24]. Alternatively, there may be a direct correlation between gene expression in circulating leukocytes that participate in the pathogenesis of arteriosclerosis. In agreement with this, previous microarray data from Huang et al. [48] have identified the differential expression of several genes in circulating cells, including calcium- and bone-related genes, in individuals with and without vascular calcification.

Using the Twins UK cohort, we have investigated the association of gene expression levels with cross-sectional and longitudinal changes in arterial stiffening [49]. Genes were selected if they had previously been associated with arterial stiffening in genome-wide or candidate gene studies. We found that expression levels of ENPP1, a transmembrane glycoprotein enzyme that generates inorganic pyrophosphate and is associated with vascular calcification, were independently associated with PWV in a cross-sectional analysis. These findings were successfully replicated in a longitudinal analysis where ENPP1 was a significant predictor of aPWV progression. We additionally found expression levels of COL4A1, which encodes for one component of type IV collagen, to be significantly associated with progression of PWV. Possible biological pathways and gene networks linking ENPP1 and COL4A1 to arterial stiffness and calcification were identified using the Ingenuity Knowledge Base (fig. 1) [49]. 


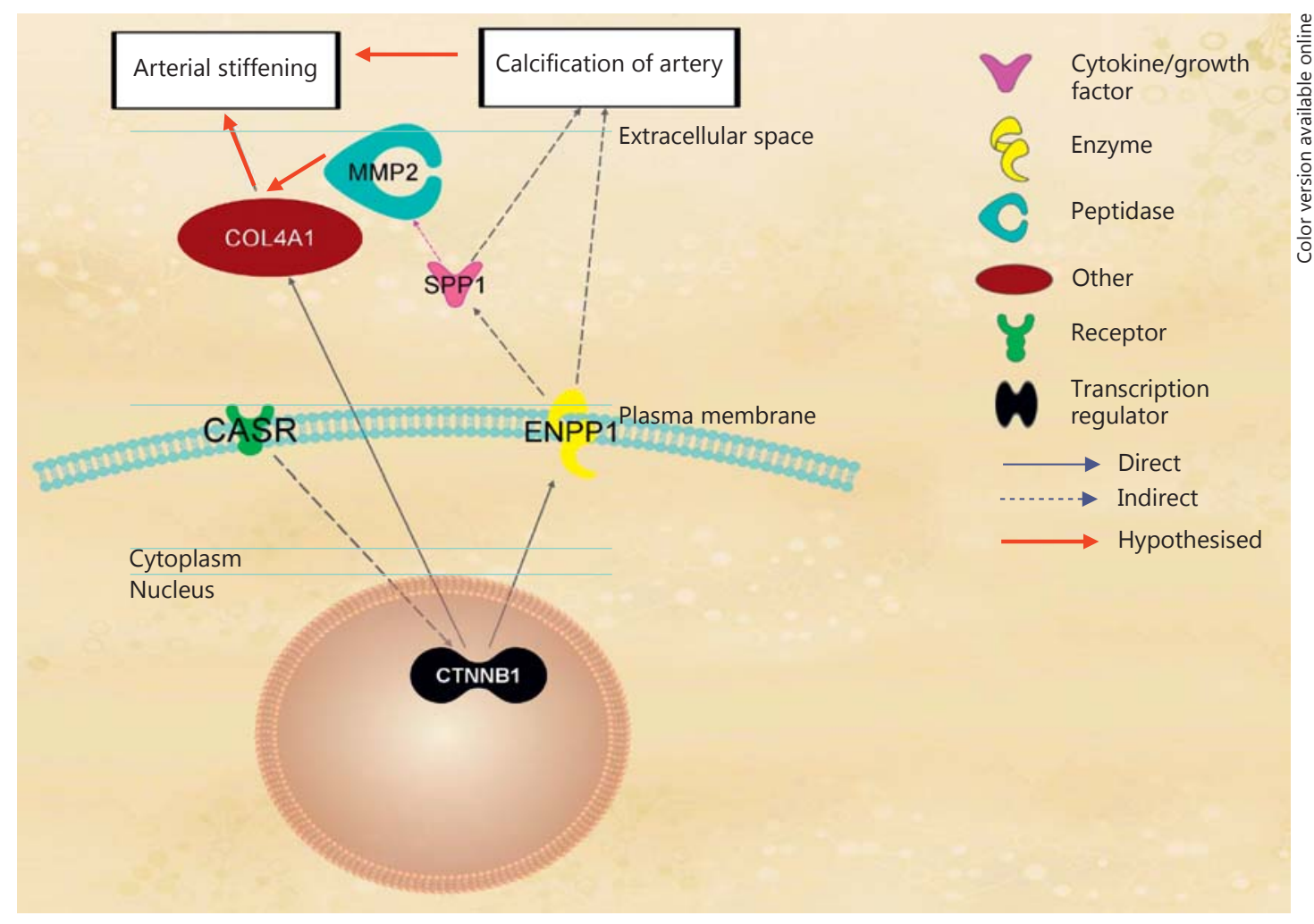

Fig. 1. Conceptual pathway linking COL4A1 and ENPP1 with arterial stiffness using the Ingenuity Pathway Analysis knowledge database. Activation of the calcium-sensing receptor (CASR) acts on the transcriptional regulator catenin (cadherin-associated protein) beta 1 (CTNNB1) which initiates the transcription of ENPP1 and COL4A1. Increased ENPP1 expression may lead to arterial stiffening through its effect on calcification, or it may trigger osteopontin (SPP1) and influence the extracellular matrix through its effects on MMP2/9 [49].

\section{Conclusion}

Despite the prognostic importance of arterial stiffness, very little is known regarding the molecular mechanisms of stiffening. Unique approaches utilising both genetic variants and gene expression data and their associations with particular phenotypes may help to identify novel pathways, likely involving calcification/extracellular matrix degradation, for interventions to prevent or reverse arterial stiffening. In particular, combining this with longitudinal studies may elucidate different mechanisms determining arterial stiffness at different vascular ages that are specific to the human aorta. Due to the unique characteristics of the human aorta with the predominance of extracellular matrix and coexistent atheromatous disease, animal models may be of limited use in identifying such mechanisms but could be important for validating the findings of genetic studies to test the role of genes in pathways influencing both muscular and elastic arteries.

\section{Disclosure Statement}

The authors declare that they have no conflicts of interest. 
Cecelja and Chowienczyk: Molecular Mechanisms of Arterial Stiffening

\section{References}

1 Avolio AP, Chen SG, Wang RP, Zhang CL, Li MF, O'Rourke MF: Effects of aging on changing arterial compliance and left ventricular load in a northern Chinese urban community. Circulation 1983;68:50-58.

2 Wallace SM, Yasmin, McEniery CM, Maki-Petaja KM, Booth AD, Cockcroft JR, et al: Isolated systolic hypertension is characterized by increased aortic stiffness and endothelial dysfunction. Hypertension 2007;50: 228-233.

3 Cecelja M, Chowienczyk P: Role of arterial stiffness in cardiovascular disease. JRSM Cardiovasc Dis 2012;1.

4 Cecelja M, Jiang B, Spector TD, Chowienczyk P: Progression of central pulse pressure over 1 decade of aging and its reversal by nitroglycerin: a twin study. J Am Coll Cardiol 2012;59:475-483.

5 Willum-Hansen T, Staessen JA, Torp-Pedersen C, Rasmussen S, Thijs L, Ibsen H, et al: Prognostic value of aortic pulse wave velocity as index of arterial stiffness in the general population. Circulation 2006;113:664-670.

6 Laurent S, Cockcroft J, Van Bortel L, Boutouyrie P, Giannattasio C, Hayoz D, et al: Expert consensus document on arterial stiffness: methodological issues and clinical applications. Eur Heart J 2006;27:2588-2605.

7 van Popele NM, Grobbee DE, Bots ML, Asmar R, Topouchian J, Reneman RS, et al: Association between arterial stiffness and atherosclerosis: the Rotterdam study. Stroke 2001;32:454-460.

8 Cecelja M, Hussain T, Greil G, Botnar R, Preston R, Moayyeri A, et al: Multimodality imaging of subclinical aortic atherosclerosis: relation of aortic stiffness to calcification and plaque in female twins. Hypertension 2013;61: 609-614.

9 Cecelja M, Jiang B, Bevan L, Frost ML, Spector TD, Chowienczyk PJ: Arterial stiffening relates to arterial calcification but not to noncalcified atheroma in women. A twin study. J Am Coll Cardiol 2011;57:1480-1486.

10 Farrar DJ, Bond MG, Riley WA, Sawyer JK: Anatomic correlates of aortic pulse wave velocity and carotid artery elasticity during atherosclerosis progression and regression in monkeys. Circulation 1991;83:1754-1763.

11 Cecelja M, Chowienczyk P: Dissociation of aortic pulse wave velocity with risk factors for cardiovascular disease other than hypertension: a systematic review. Hypertension 2009;54:1328-1336.

12 Demer LL, Tintut Y: Vascular calcification: pathobiology of a multifaceted disease. Circulation 2008;117: 2938-2948.

13 Demer LL: Vascular calcification and osteoporosis: inflammatory responses to oxidized lipids. Int J Epidemiol 2002;31:737-741.

14 Niederhoffer N, Lartaud-Idjouadiene I, Giummelly P, Duvivier C, Peslin R, Atkinson J: Calcification of medial elastic fibers and aortic elasticity. Hypertension 1997;29:999-1006.

15 Kim KM: Calcification of matrix vesicles in human aortic valve and aortic media. Fed Proc 1976;35:156-162.

16 Reynolds JL, Joannides AJ, Skepper JN, McNair R, Schurgers LJ, Proudfoot D, et al: Human vascular smooth muscle cells undergo vesicle-mediated calcification in response to changes in extracellular calcium and phosphate concentrations: a potential mechanism for accelerated vascular calcification in ESRD. J Am Soc Nephrol 2004;15:2857-2867.

17 Farzaneh-Far A, Proudfoot D, Weissberg PL, Shanahan CM: Matrix gla protein is regulated by a mechanism functionally related to the calcium-sensing receptor. Biochem Biophys Res Commun 2000;277:736-740.

18 Blacher J, Demuth K, Guerin AP, Safar ME, Moatti N, London GM: Influence of biochemical alterations on arterial stiffness in patients with end-stage renal disease. Arterioscler Thromb Vasc Biol 1998;18:535-541.

19 McEniery CM, Spratt M, Munnery M, Yarnell J, Lowe GD, Rumley A, et al: An analysis of prospective risk factors for aortic stiffness in men: 20-year follow-up from the Caerphilly prospective study. Hypertension 2010;56: 36-43.

20 Duca L, Floquet N, Alix AJ, Haye B, Debelle L: Elastin as a matrikine. Crit Rev Oncol Hematol 2004;49:235-244.

21 Basalyga DM, Simionescu DT, Xiong W, Baxter BT, Starcher BC, Vyavahare NR: Elastin degradation and calcification in an abdominal aorta injury model: role of matrix metalloproteinases. Circulation 2004;110:34803487.

22 Yasmin, McEniery CM, O’Shaughnessy KM, Harnett P, Arshad A, Wallace S, et al: Variation in the human matrix metalloproteinase-9 gene is associated with arterial stiffness in healthy individuals. Arterioscler Thromb Vasc Biol 2006;26:1799-1805.

23 Yasmin, McEniery CM, Wallace S, Dakham Z, Pulsalkar P, Maki-Petaja K, et al: Matrix metalloproteinase-9 (MMP-9), MMP-2, and serum elastase activity are associated with systolic hypertension and arterial stiffness. Arterioscler Thromb Vasc Biol 2005;25:372.

24 Maclay JD, McAllister DA, Rabinovich R, Haq I, Maxwell S, Hartland S, et al: Systemic elastin degradation in chronic obstructive pulmonary disease. Thorax 2012;67:606-612.

25 Steed MM, Tyagi SC: Mechanisms of cardiovascular remodeling in hyperhomocysteinemia. Antioxid Redox Signal 2011;15:1927-1943.

26 Mitchell GF, DeStefano AL, Larson MG, Benjamin EJ, Chen MH, Vasan RS, et al: Heritability and a genome-wide linkage scan for arterial stiffness, wave reflection, and mean arterial pressure: the Framingham Heart Study. Circulation 2005;112:194-199.

27 North KE, MacCluer JW, Devereux RB, Howard BV, Welty TK, Best LG, et al: Heritability of carotid artery structure and function: the Strong Heart Family Study. Arterioscler Thromb Vasc Biol 2002;22:1698-1703.

28 Sayed-Tabatabaei FA, van Rijn MJ, Schut AF, Aulchenko YS, Croes EA, Zillikens MC, et al: Heritability of the function and structure of the arterial wall: findings of the Erasmus Rucphen Family (ERF) study. Stroke 2005; 36:2351-2356. 
Cecelja and Chowienczyk: Molecular Mechanisms of Arterial Stiffening

29 Medley TL, Cole TJ, Dart AM, Gatzka CD, Kingwell BA: Matrix metalloproteinase-9 genotype influences large artery stiffness through effects on aortic gene and protein expression. Arterioscler Thromb Vasc Biol 2004; 24:1479-1484

30 Medley TL, Kingwell BA, Gatzka CD, Pillay P, Cole TJ: Matrix metalloproteinase-3 genotype contributes to agerelated aortic stiffening through modulation of gene and protein expression. Circ Res 2003;92:1254-1261.

31 Brull DJ, Murray LJ, Boreham CA, Ralston SH, Montgomery HE, Gallagher AM, et al: Effect of a COL1A1 Sp1 binding site polymorphism on arterial pulse wave velocity: an index of compliance. Hypertension 2001;38: 444-448.

32 Medley TL, Cole TJ, Gatzka CD, Wang WY, Dart AM, Kingwell BA: Fibrillin-1 genotype is associated with aortic stiffness and disease severity in patients with coronary artery disease. Circulation 2002;105:810-815.

33 Eller P, Hochegger K, Feuchtner GM, Zitt E, Tancevski I, Ritsch A, et al: Impact of ENPP1 genotype on arterial calcification in patients with end-stage renal failure. Nephrol Dial Transplant 2008;23:321-327.

34 Benetos A, Gautier S, Ricard S, Topouchian J, Asmar R, Poirier O, et al: Influence of angiotensin-converting enzyme and angiotensin II type 1 receptor gene polymorphisms on aortic stiffness in normotensive and hypertensive patients. Circulation 1996;94:698-703.

35 Chen W, Srinivasan SR, Boerwinkle E, Berenson GS: Beta-adrenergic receptor genes are associated with arterial stiffness in black and white adults: the Bogalusa Heart Study. Am J Hypertens 2007;20:1251-1257.

36 Czarnecka D, Kawecka-Jaszcz K, Stolarz K, Olszanecka A, Dembinska-Kiec A, Kiec-Wilk B: Ambulatory blood pressure, left ventricular mass and vascular phenotypes in relation to the endothelial nitric oxide synthase gene Glu298Asp and intron 4 polymorphisms in a population-based family study. J Hum Hypertens 2005;19: 413-420.

37 Morita A, Nakayama T, Doba N, Hinohara S, Soma M: Polymorphism of the C-reactive protein (CRP) gene is related to serum CRP level and arterial pulse wave velocity in healthy elderly Japanese. Hypertens Res 2006; 29:323-331.

38 Schnabel R, Larson MG, Dupuis J, Lunetta KL, Lipinska I, Meigs JB, et al: Relations of inflammatory biomarkers and common genetic variants with arterial stiffness and wave reflection. Hypertension 2008;51:1651-1657.

39 Tarasov KV, Sanna S, Scuteri A, Strait JB, Orru M, Parsa A, et al: COL4A1 is associated with arterial stiffness by genome-wide association scan. Circ Cardiovasc Genet 2009;2:151-158.

40 Mitchell GF, Verwoert GC, Tarasov KV, Isaacs A, Smith AV, Yasmin, et al: Common genetic variation in the 3'BCL11B gene desert is associated with carotid-femoral pulse wave velocity and excess cardiovascular disease risk: the AortaGen Consortium. Circ Cardiovasc Genet 2012;5:81-90.

41 Steves CJ, Spector TD, Jackson SH: Ageing, genes, environment and epigenetics: what twin studies tell us now, and in the future. Age Ageing 2012;41:581-586.

42 Zhang W, Li F, Nie L: Integrating multiple 'omics' analysis for microbial biology: application and methodologies. Microbiology 2010;156:287-301.

43 Elashoff MR, Nuttall R, Beineke P, Doctolero MH, Dickson M, Johnson AM, et al: Identification of factors contributing to variability in a blood-based gene expression test. PLoS One 2012;7:e40068.

44 Elashoff MR, Wingrove JA, Beineke P, Daniels SE, Tingley WG, Rosenberg S, et al: Development of a blood-based gene expression algorithm for assessment of obstructive coronary artery disease in non-diabetic patients. BMC Med Genomics 2011;4:26.

45 Rosenberg S, Elashoff MR, Beineke P, Daniels SE, Wingrove JA, Tingley WG, et al: Multicenter validation of the diagnostic accuracy of a blood-based gene expression test for assessing obstructive coronary artery disease in nondiabetic patients. Ann Intern Med 2010;153:425-434.

46 Rosenberg S, Elashoff MR, Lieu HD, Brown BO, Kraus WE, Schwartz RS, et al: Whole blood gene expression testing for coronary artery disease in nondiabetic patients: major adverse cardiovascular events and interventions in the PREDICT trial. J Cardiovasc Transl Res 2012;5:366-374.

47 Huan T, Esko T, Peters MJ, Pilling LC, Schramm K, Schurmann C, et al: A meta-analysis of gene expression signatures of blood pressure and hypertension. PLoS Genet 2015;11:e1005035.

48 Huang CC, Lloyd-Jones DM, Guo X, Rajamannan NM, Lin S, Du P, et al: Gene expression variation between African Americans and whites is associated with coronary artery calcification: the multiethnic study of atherosclerosis. Physiol Genomics 2011;43:836-843.

49 Cecelja M, Jiang B, Mangino M, Spector TD, Chowienczyk PJ: Association of cross-sectional and longitudinal change in arterial stiffness with gene expression in the Twins UK cohort. Hypertension 2016;67:70-76. 